\title{
Flood and Irrigation Map using geographic Information System (GIS) (A Case Study of Ido Catchment Area)
}

\author{
Akolade, A.S ${ }^{1 *}$, Oyekanmi, O. A ${ }^{2}$, Aleshinloye, A. O ${ }^{3}$, Sowemimo, A.O ${ }^{4}$ \\ ${ }^{1}$ Department of Civil Engineering, Lead City University, Ibadan, Nigeria. \\ ${ }^{2}$ Works and Services Department, Osun State Polytechnic, Iree, Nigeria. \\ ${ }^{3}$ Department of Civil Engineering, University of Ibadan, Ibadan Nigeria. \\ ${ }^{4}$ Department of Civil Engineering, The Polytechnic, Ibadan,Ibadan, Nigeria.
}

*Corresponding Author: Akolade, A.S, Department of Civil Engineering, Lead City University, Ibadan, Nigeria.

\begin{abstract}
Water resources issues and problems in the world's developing countries, or lesser developed countries present special management challenges. Irrigation is one of the most important inputs for an efficient and sustainable Industrial, and agricultural production. Irrigation management in the most projects so far has been essentially water supply based. The dynamics of general water demands are not explicitly considered. Consequently, irrigation systems do not supply the right quantities of water at the right time.

The assessment of management strategies requires the analysis of the current irrigation and drainage system and prediction of the potential changes to various parameters.

Several layers of map information such as: The Topographical map shows the physiographical features of the catchment area.The Digital Elevation Measurement (DEM) shows the elevations of the catchment area ranging between $86 m-276 m$ respectively indicating areas of low and high elevations within the catchment cardinals, Flow Direction, Flood-Plain, Study Area, and land-use map. The Triangulated Irregular Network (TIN) shows region of high and low elevations in coloration, and The Irrigation suitability Zone maps shows that areas of low elevations are more suitable for irrigation system work, and similarly prone to flooding which are of notable height range between 86-100m, 100-120m, 120-140m, 140-160m, and 160$180 \mathrm{~m}$, and areas that are advised for industrialization of notable high elevations ranges from 180-200m, 200-220m, 220-240m, 240-260m, 260-276m.

Some of the areas that are most suitable for mounting irrigation system in IdoCatchment area due to their ability to conserve water are Ogbontosa, bale, beko,jakaetc and these areas mentioned are as well prone to flood disasters. It is therefore recommended that: The identified surface irrigation potential of the river catchment in the study area can assist in policy decisions during a development of irrigation project and Communities should be strongly discouraged from settling within the flood plains.
\end{abstract}

Keywords: Irrigation management, GIS, TIN, Flood-Plain, Catchment Area

\section{INTRODUCTION}

Water resources issues and problems in the world's developing countries, or lesser developed countries present special management challenges. These issues and problems include inadequate drinking-water supply, lack of sanitation facilities, water pollution, floods, the siltation of river systems and the management of rivers and large dams. These problems are more severe and widespread in the developing countries (Bartram, 2012).

Modern method of irrigation system compensates disadvantages of traditional methods and thus helps in the proper way of water usage. The modern method involves two systems: Sprinkler system, and Drip system. A sprinkler system as its name suggests sprinkles water over the crop and helps in an even distribution of water. This method is much advisable in areas facing water scarcity. This method can also be used in regions where water availability is less (Byjus, 2017).

Irrigated engineering construction and agricultural works generally uses large volume of water. Water resources limitations caused the water supply to become a critical issue in recent years. Thus, it is important to improve water management practices to save water for expanded engineering 

Area)

construction activities and agricultural activities and for other uses. Monitoring and performance evaluation is the key to the successful management.

Remote sensing and Geographic Information System (GIS) with their capability of data collection and analysis are now viewed as efficient and effective tools for irrigation water management. The capability of GIS to analyze information across space and time would help in managing such dynamic systems as irrigation systems. Soil survey data and GIS are important tools in land use planning. Intertwined, they represent an invaluable and underutilized resource (Minakshi, 2009).

Hence the aim of this research is to generate the flood-plain and irrigation map of Ido Local Government using Geographic Information System (GIS).

\section{STUdy AREA}

The Irrigation system to be assessed is located in Ido, Oyo State Ibadan. Ido is a Local Government in Oyo state; Nigeria and its headquarters are in the town of Ido. It has an area of $986 \mathrm{~km}^{2}$ and a population of 103,261 at the 2006 census. Ido Local Government appears on the earth's surface of central Longitude and Latitude of $7^{\circ} 32^{\prime} 30.29^{\prime}{ }^{\prime} \mathrm{N}, 3^{\circ} 39^{\prime} 45.78^{\prime}$ ' $\mathrm{E}$, the uppermost boundary cardinals of $7^{\circ} 45^{\prime} 36.952^{\prime \prime} \mathrm{N}, 3^{\circ} 40^{\prime} 9.35^{\prime}$ ' $\mathrm{E}$, the lowest boundary cardinals of $7^{\circ} 16^{\prime} 22.54^{\prime}{ }^{\prime} \mathrm{N}, 3^{\circ} 43^{\prime} 18.17 \mathrm{E}$ " also the cardinals to the left and right boundaries are stated as thus, $7^{\circ} 25^{\prime} 33.25^{\prime}{ }^{\prime} \mathrm{N}, 3^{\circ} 28^{\prime} 52.759 \mathrm{E}$ ' and $7^{\circ} 27^{\prime} 15.53^{\prime}$ 'N , 3 50 '30.87' $\mathrm{E}$ as shown in Fig 1. below. Ido Local Government was among the five in Ibadan district before it was cancelled in 1956 (NIPOST, 2009).

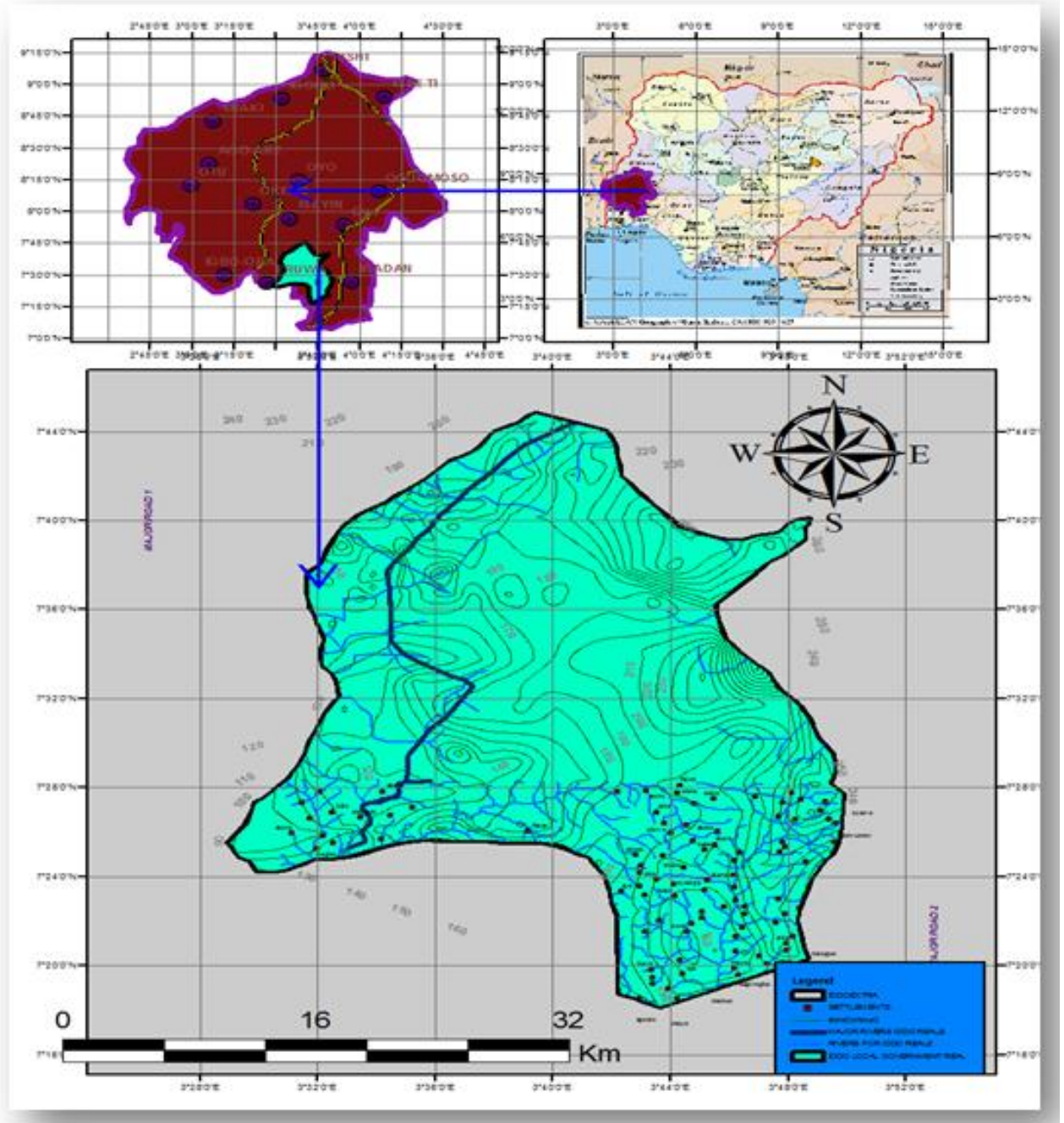

Fig1. Digitized Study Map of Ido Catchment Area

\section{Methodology}

The use of GIS to design and plan irrigation systems requires a procedure for adequate analysis and its shown in Fig 2 below. 
Flood and Irrigation Map using geographic Information System (GIS) (A Case Study of Ido Catchment Area)

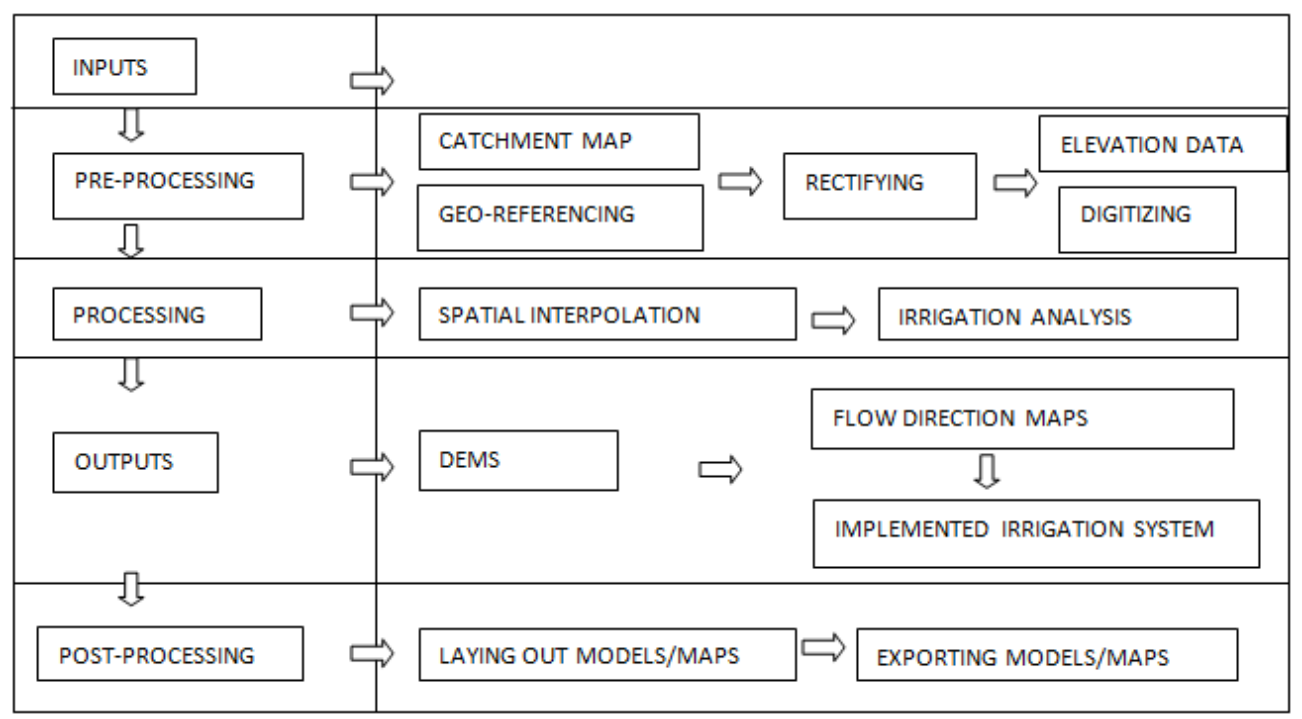

Fig2. A Flow Diagram Showing Irrigation and Floodplain Maps Generation

\section{RESULTS AND DISCUSSION}

The results of this work including the production of the topographical map and the Digital Elevation Model (DEM) map of Ido catchment, which is subsequently used to generate the flow direction map, and the flow accumulation map of Ido local government as shown in the figures and tables below, are illustrated in this research.

\subsection{Topographical Map of Ido Catchment Area}

The co-ordinates on the digitized Topographical map have distinctive elevations; the areas that are of the same elevations are connected by a contour line as shown in Fig 3. The generation of the topographical map was digitized from the conjoined western topographical map which comprises of Ogun state, Ijebu-Ode and part of Ibadan, while part of the features of the topographical map was digitized with remote sensing using Google earth map 2019 model.

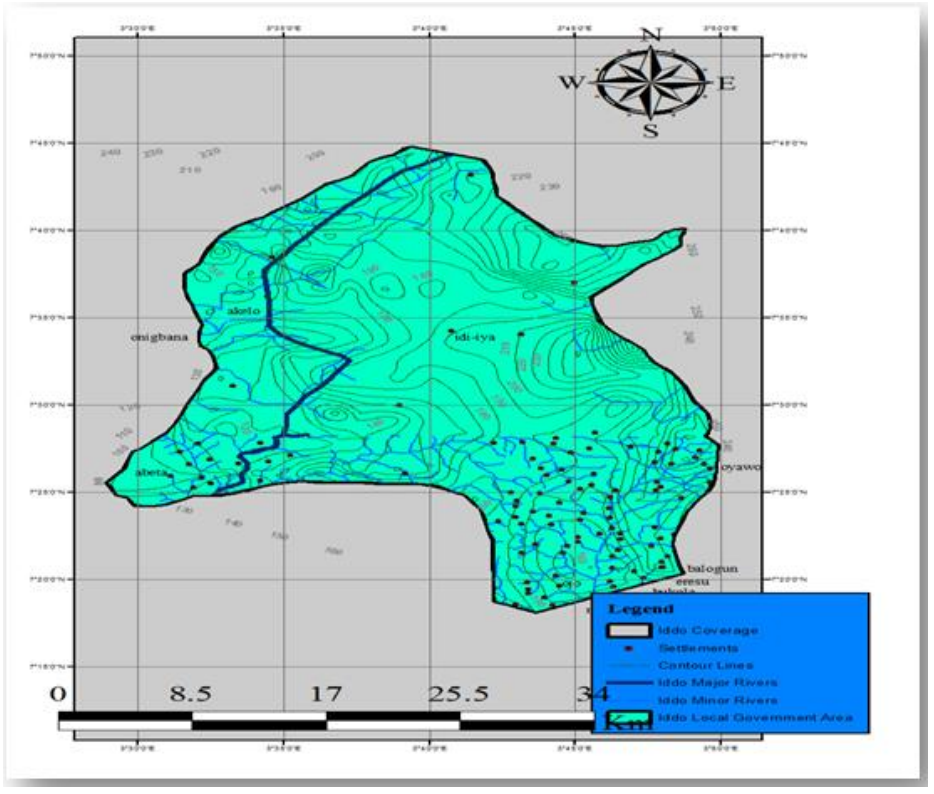

Fig3. Topographical Map of Ido Catchment Area

\subsection{Digital Elevation Measurement (DEM) Map and the Generational Elevation Map of Ido Local Government Catchment Area}

The Digital Elevation Measurement (DEM) map shows the coloration distinguishing factor of the variation in heights, indicating the yellowish, greenish and bluish part to be the lowest terrain, fairly hilly terrain, and the hilly terrain with the highest elevations as shown in Fig 4a, while Fig 4b shows 

Area)

the generational map that was used to create the DEM map. The elevation values ranges between $86 \mathrm{~m}-276 \mathrm{~m}$ respectively.

The Digital Elevation Measurement (DEM) map can also be used for hydrological purposes to produce the flow direction and flow accumulation map. These are hereby considered in the next section of this chapter.

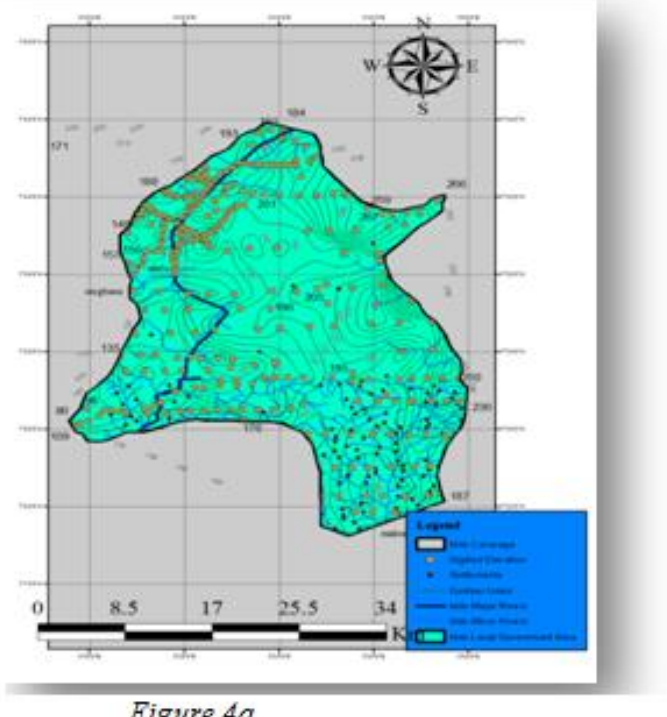

Figure $4 a$

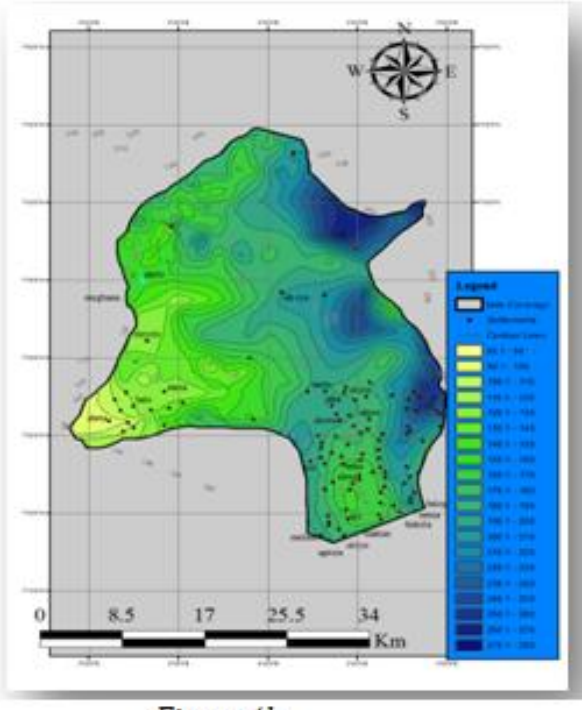

Figure $4 b$

Fig4a. The Elevation Map/Generational Map of Ido Catchment Area

Fig4b. DEM Map of IdoCatchment Area (2019)

\subsection{Hydrological Map of Ido Catchment Area}

The hydrological maps of Ido local government are maps that show the features of water flow in the study area, such as direction of flow of water, and flow accumulation, the flood plain of the catchment area and so on. The maps generated from this chapter are the flow direction map, and the Triangulated Irregular Network (TIN) map.

\subsubsection{Flow Direction Map}

The distinguishing factor of the flow direction map is the color distinctiveness. Areas that are yellowish, and bluish, in color indicates places of high and moderate flow direction, while the extremely bluish and sky bluish color symbol indicates the area of low flow direction and the extremely low flow direction area, water flow will possibly be directed to areas with yellow color as indicated in Flow direction map of Ido catchment area shown in Fig 5.

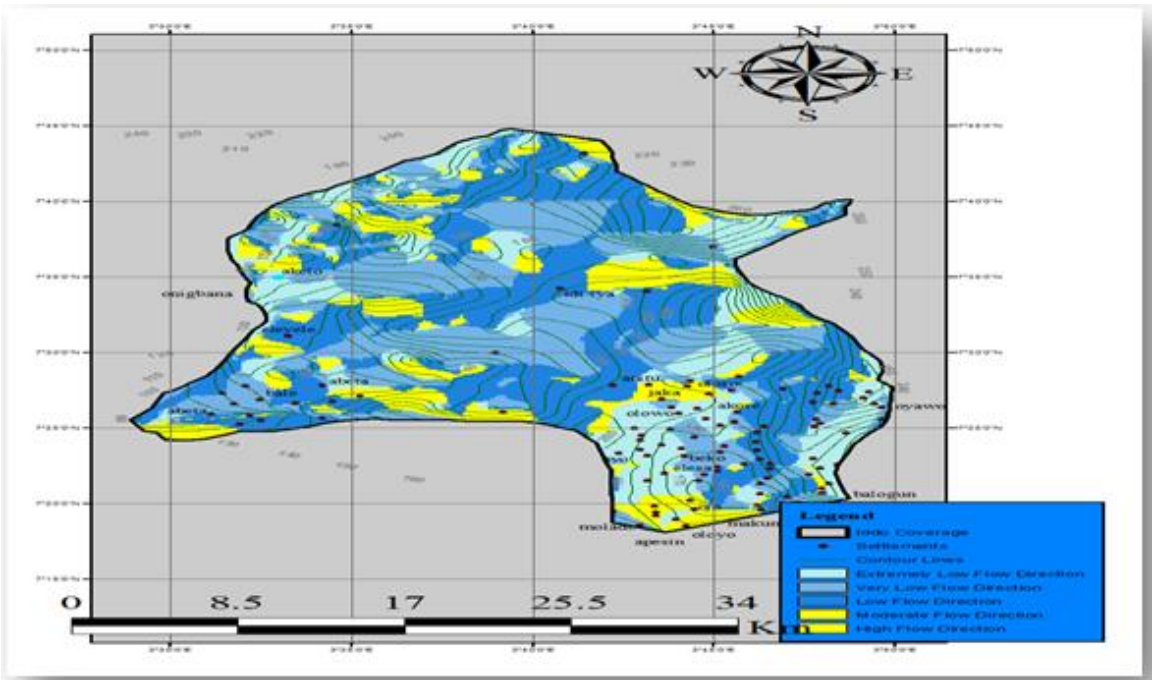

Fig5. Flow Direction Map of Ido Catchment Area (2019) 
Flood and Irrigation Map using geographic Information System (GIS) (A Case Study of Ido Catchment Area)

Table1. Flow Direction Values of Co-Ordinates in Ido Catchment Area

\begin{tabular}{|c|c|c|c|c|}
\hline $\mathbf{S} / \mathbf{N}$ & Co-Ordinate & $\begin{array}{c}\text { Flow } \\
\text { Direction } \\
\text { Value } \\
\end{array}$ & $\begin{array}{c}\text { Flow } \\
\text { Direction } \\
\text { Symbol } \\
\end{array}$ & Comments \\
\hline 1 & 3 39' 47.094"E, 7 43' 36.782"N & High & Yellow & $\begin{array}{l}\text { Water flows into the area from many } \\
\text { directions }\end{array}$ \\
\hline 2 & 3 34' 48.601"E, 7 39' 33.566"N & High & Yellow & $\begin{array}{l}\text { Water flows into the area from many } \\
\text { directions }\end{array}$ \\
\hline 3 & $33^{\prime} 10.243 " \mathrm{E}, 7$ 39' 44.621"N & Low & Sky Blue & $\begin{array}{l}\text { Water flows into the area from minute } \\
\text { directions }\end{array}$ \\
\hline 4 & 3 42' 47.663"E, 7 35' 22.980"N & High & Yellow & $\begin{array}{l}\text { Water flows into the area from many } \\
\text { directions }\end{array}$ \\
\hline 5 & 3 33' 31.214"E, 7 32' 22.410"N & High & Yellow & $\begin{array}{c}\text { Water flows into the area from many } \\
\text { directions }\end{array}$ \\
\hline 6 & 3 38' 26.022"E, 7 32' 55.576"N & Very Low & Blue & $\begin{array}{l}\text { Little or no water flows into this } \\
\text { direction. }\end{array}$ \\
\hline 7 & 3 41' 4.4810"E, 7 33' 2.9460"N & Low & Sky Blue & $\begin{array}{l}\text { Water flows into the area from minute } \\
\text { directions }\end{array}$ \\
\hline 8 & 3 44' 8.7350"E, 7 33' 10.316"N & Very Low & Blue & $\begin{array}{l}\text { Little or no water flows into this } \\
\text { direction. }\end{array}$ \\
\hline 9 & 3 46' 43.509"E, 7 32' 29.780"N & High & Yellow & $\begin{array}{l}\text { Water flows into the area from many } \\
\text { directions }\end{array}$ \\
\hline 10 & 3 31' 36.976"E, 728 ' 56.045"N & Very Low & Blue & $\begin{array}{l}\text { Little or no water flows into this } \\
\text { direction. }\end{array}$ \\
\hline 11 & $32^{\prime} 50.678 " \mathrm{E}, 728^{\prime} 15.509 " \mathrm{~N}$ & High & Yellow & $\begin{array}{l}\text { Water flows into the area from many } \\
\text { directions }\end{array}$ \\
\hline 12 & 3 34' 30.176"E, 7 28' 33.935"N & Low & Sky Blue & $\begin{array}{c}\text { Water flows into the area from minute } \\
\text { directions }\end{array}$ \\
\hline 13 & $33^{\prime} 41.800 " \mathrm{E}, 728^{\prime} 37.620 " \mathrm{~N}$ & High & Yellow & $\begin{array}{l}\text { Water flows into the area from many } \\
\text { directions }\end{array}$ \\
\hline 14 & $33^{\prime} 58.149^{\prime \prime} \mathrm{E}, 728^{\prime} 52.360 " \mathrm{~N}$ & Very Low & Blue & $\begin{array}{l}\text { Little or no water flows into this } \\
\text { direction. }\end{array}$ \\
\hline 15 & 3 44' 1.3650"E, $728^{\prime} 48.675^{\prime \prime} \mathrm{N}$ & Low & Sky Blue & $\begin{array}{l}\text { Water flows into the area from minute } \\
\text { directions }\end{array}$ \\
\hline 16 & 3 47' 53.526"E, 7 29' 7.1000"N & Very Low & Blue & $\begin{array}{l}\text { Little or no water flows into this } \\
\text { direction. }\end{array}$ \\
\hline 17 & 3 34' 55.971"E, 7 26' 32.326"N & Very Low & Blue & $\begin{array}{l}\text { Little or no water flows into this } \\
\text { direction. }\end{array}$ \\
\hline 18 & 3 36' 39.154"E, 7 26' 21.271"N & High & Yellow & $\begin{array}{l}\text { Water flows into the area from many } \\
\text { directions }\end{array}$ \\
\hline 19 & $340^{\prime} 31.315^{\prime \prime} \mathrm{E}, 726^{\prime} 54.437 " \mathrm{~N}$ & Very Low & Blue & $\begin{array}{l}\text { Little or no water flows into this } \\
\text { direction. }\end{array}$ \\
\hline 20 & 3 44' 27.161"E, 7 19' 13.801"N & High & Yellow & $\begin{array}{l}\text { Water flows into the area from many } \\
\text { directions }\end{array}$ \\
\hline
\end{tabular}

\subsection{Area of Suitability for Irrigation System Map of Ido Catchment Area}

The Triangulated Irregular Network (TIN) of Ido local government catchment topography shown in Fig 6 explains the areas that are suitable for the mounting of irrigation system with the fact that water flows from the region of high elevation to region of low elevation. The TIN map identifies the elevation features of Ido local government catchment in 3D view, as well as merging area formations with the contour line, making the elevation outstretch of the map more visible.

Conclusively areas that are red in colour should be recommended exclusively for irrigation and agricultural purpose which falls in the south-western and western region of Ido local government catchment, examples of south-western region that falls between the red zone areas are abeta, alagba, bale, and olapade. 


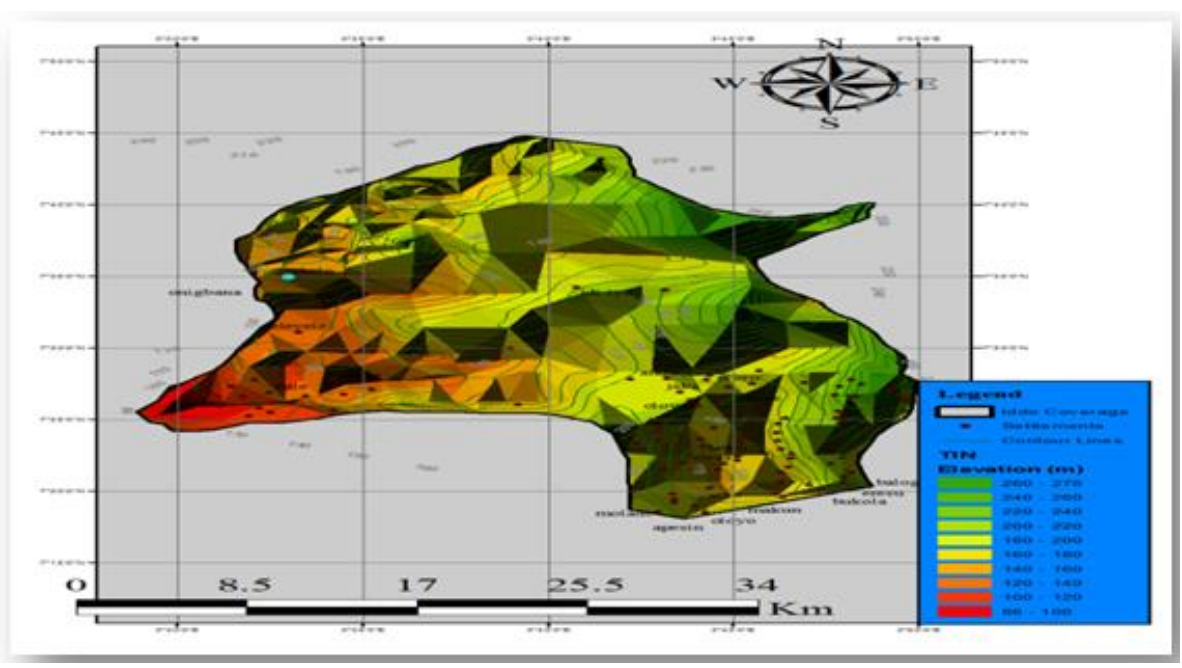

Fig6. Map Showing the TIN of Suitable Zones for Agricultural Practice in Ido Local Government

\subsection{Flood Risk Map of Ido Catchment Area}

The advantage of water flow towards the south west of Ido local government which makes it fit for agricultural practice is also a possibility and at disadvantage that the south-western part of Ido local government is prone to flooding hence, Fig 7 shows the flood risk map of Ido local government catchment. The flood elevation map of Ido local government catchment explains the areas that are prone to flood going with the fact that water willflow from areas of high elevation to areas of low elevation. The areas that are black in colour are of low elevation and are therefore at the flood risk zone. The flood risk areas include;Abeta, Ogunde, Eleyele, Bale and Onigbana, and it is therefore suggested that flood zone should be under professional speculations, and main water bodies could also be properly dammed for collective accumulation of water.

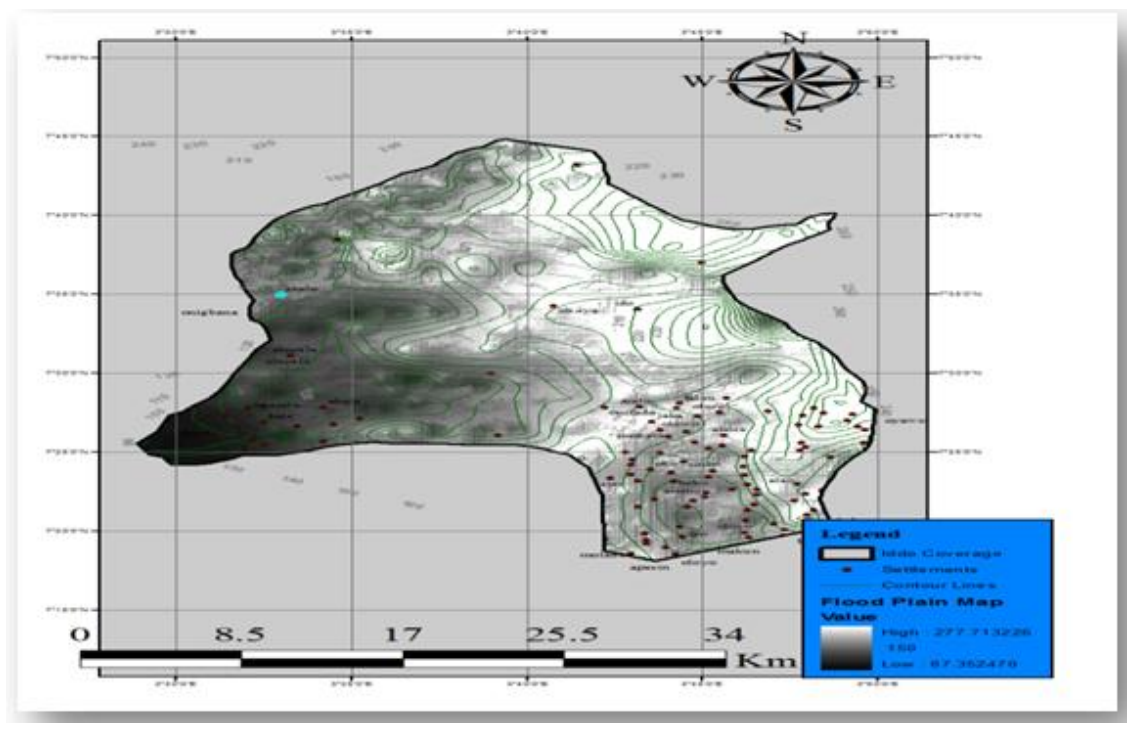

Fig7. Flood Risk Map of Ido Catchment Area

\subsection{Study Area Map and Land Use Pattern Map of Ido Catchment Area}

The land use pattern map (Fig 8b) was regenerated from the study area map (Fig 8a) of Ido local government using the Reclass tool from the interpolation function of ArcGIS software. The land use pattern map of Ido local government demonstrates the features of Ido local government using distinctive colours, the classification of the features on the land use pattern map are the vegetal areas, semi built-up areas, built up areas and water bodies. Similarly the feature deductions were made from the map legend using distinctive colour classification which gives the information about the features of Ido local government land use pattern indicating the greenish part of the area to be vegetal areas, the yellow areas being the semi-built-up areas, the brownish areas being the built-up areas, while the areas represented in blue is that of an existing water body. 

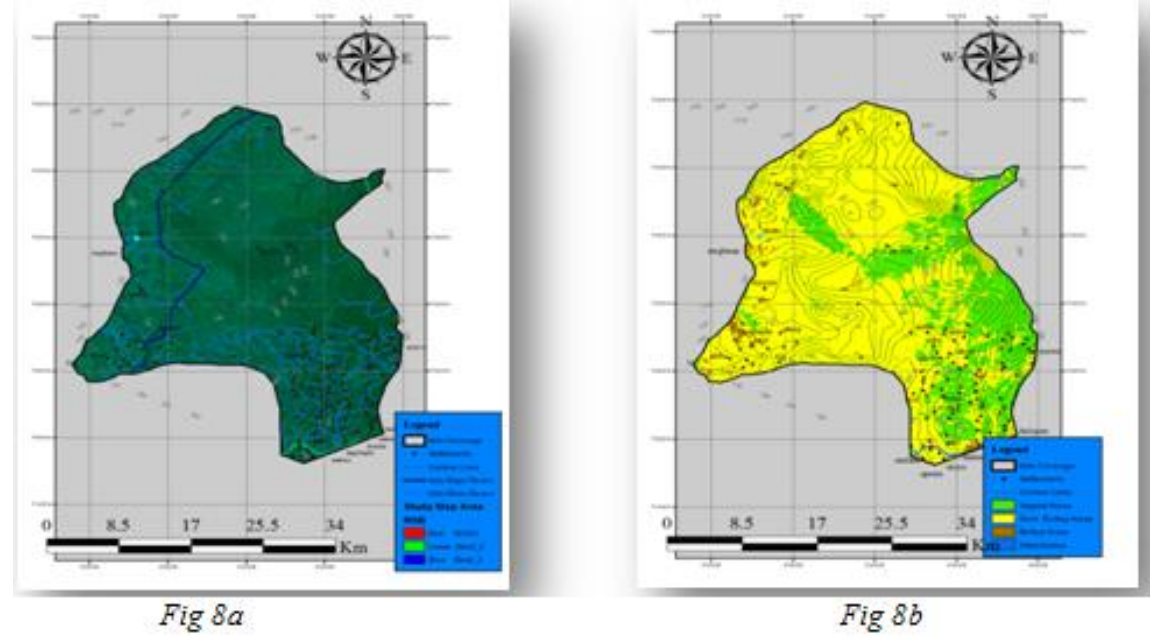

Fig8a. Study Area Map of Ido Catchment Area

Fig8b. Land Use Pattern Map of Ido Catchment Area

\subsection{Irrigation System Suitability Zone Map}

The Irrigation suitability zone map as shown in Fig 4.7 indicates the areas that are suitable and extremely suitable for siting an irrigation system facility to be of $25 \%$ of Ido local government. Using the legend classification and interpretation method, the map (Fig 9) classifies Ido local government prior to irrigation system in four classifications which are;the slightly suitable zone, the suitable zone, the highly suitable zone, the extremely suitable zone.

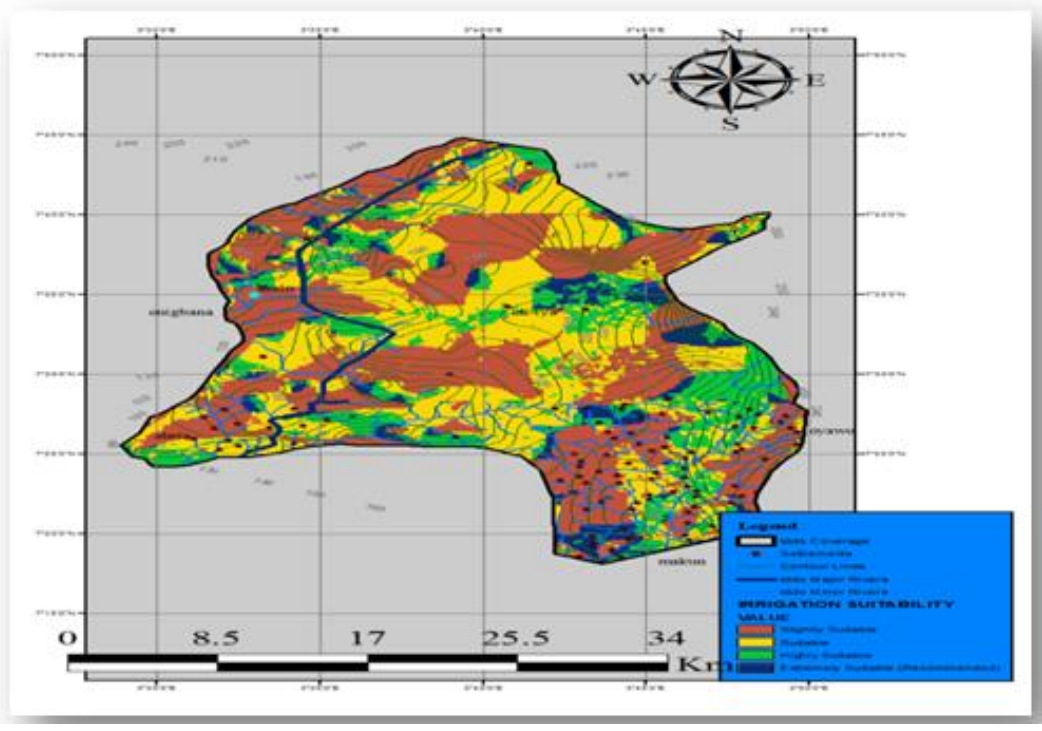

Fig9. Irrigation Suitability Zone Map of Ido Local Government Catchment

\section{CONCLUSIONS AND RECOMMENDATION}

The following conclusions were made on the findings from this research;

The topographical and digital elevation (DEM) map of Ido local government catchments shows that the south-western part of Ido local government has the lowest elevation which makes it advantageous for agricultural activities, and the susceptibility to water flow also indicates its vulnerability to flooding as indicated by the flood plain map, hence the reason for the construction of Eleyele dam is justified. The flow direction map of Ido local government shows that other than agricultural activities Ido local government will perform well in urbanization and industrialization free of risk to flooding due to its extremely high elevation terrain dispersed around its horizon.The land-use pattern map of Ido local government catchment shows that Ido local government is an underdeveloped area due to the famous agricultural activities in about $75-80 \%$ of the whole of Ido.Finally, the irrigation suitability zone map shows the detailed area where irrigation system is best to be constructed in Ido local 

Area)

government and which is sure to satisfy the need for irrigation water across all bisected cardinals in Ido local government, of places like Ogbontosa, bale, beko, jaka, etc., where these areas are notably of low elevations.

Irrigation is considered an important investment for improving rural income through increased agricultural production and consistent bounty. However this can be achieved by assessing available land and water resources for irrigation, hence, the following are hereby recommended as a distinct way forward in adequate and sufficient water supply to Agricultural sites and other water consuming activities in the study area.

The identified surface irrigation potential of the river catchment in the study area can assist in policy decisions during a development of irrigation project.

The development of flood contingency master plan for the flood plains in Ido local government catchment and Nigeria at large is imperative and extremely important.

\section{REFERENCES}

[1] Aeryon Announces Version 5, of the Aeryon Scout System, Aeryon Labs Inc". Aeryon.com. 2011-0706.Retrieved 2019-05-13.

[2] Alvankar, R., M.H. Mousavizadeh 2000, Application of GIS in water resources studies, Fourth Conference of Iranian Commission on Large Dams, 30-37.Tehran, Iran.

[3] Amor, V. M., Das Gupta1, A., Loof, R. 2002, Application of GIS and Crop Growth Models in Estimating Water Productivity. Journal of Agricultural Water Management, 54: 205-225. Aronof, S. 1991. Geographic Information Systems.2nd editopn. Ottawa: WDL publications, Canada.

[4] Bartram, 2012, Water resources issues and problems in the world's developing countries and drinkingwater supply.

[5] Chartres, C. and Varma, S. Out of water. From Abundance to Scarcity and How to Solve the World's Water Problems FT Press (USA), 2010

[6] Chang, K. T. (2008). Introduction to Geographical Information Systems. New York: McGraw Hill. p.184.

[7] Chang, K. T. (1989). "A comparison of techniques for calculating gradient and aspect from a gridded digital elevation model". International Journal of Geographical Information Science.

[8] Clarke, K. C., 1986. Advances in geographic information systems (GIS), computers, environment and urban systems, Vol. 10, pp. 175-184.

[9] Minakshi Kumar Menenti, M., Azzali, S. and d'Urso, G. 2009. Management of irrigation schemes in arid countries. In: Use of Remote Sensing Techniques in Irrigation and Drainage, ed. A. Vidal, 81-98. Rome, FAO Publishing.

[10] Olaniyan, O.S and Akolade, A.S (2015), Flood plain map using Geographical information System (GIS) a case study of Ogunpa River in Ibadan, Nigeria. International journal of Energy and Enviromental Research, Vol, 3 issue 2 pp. 22-36

[11] Olaniyan, O.S, Ige, J.A, Akolade, A.S and Adisa, O.A (2015).Application of GIS in Water Management of Eleyele Catchment, South-Western Nigeria.International Institute of Science, Technology and Education.Vol. 7, No 3 pp. 9-12.

Citation: Akolade, A.S, et.al, "Flood and Irrigation Map using geographic Information System (GIS) (A Case Study of Ido Catchment Area)", International Journal of Constructive Research in Civil Engineering, 6(3), pp. 21-28 DOI: https:// doi.org/10.20431/2454-8693.0603003.

Copyright: (C) 2020 Authors, this is an open-access article distributed under the terms of the Creative Commons Attribution License, which permits unrestricted use, distribution, and reproduction in any medium, provided the original author and source are credited. 